\title{
Who Wins in International Investment Arbitration Disputes? Evidence from Latin American and Caribbean Countries' Cases under ICSID
}

\author{
Gonzalo Ruiz Diaz
}

\begin{abstract}
During the nineties, an important group of Latin American and Caribbean (LAC) countries adhered to the International Center for Settlement of Investment Disputes (ICSID) as part of a programme of measures that sought to attract foreign investment to the region. With the aim of exploring the determinants of arbitration outcomes, I use a dataset of 161 concluded disputes until 2019 corresponding to investments in LAC countries, finding evidence on the influence of parties' characteristics, the subject discussed in cases, and characteristics of the tribunal on the arbitration outcomes. I find that $50 \%$ of tribunal decisions have been favourable to either claimant investors or host countries. However, this result may be subject to sample bias if information of settlements and discontinued cases is not taken into consideration. I also find evidence in favour of selection and party capability theories that helps to explain the determinants of international investment arbitration dispute outcomes. In particular, the results reveal that disputes related to direct expropriations have a relatively higher probability of being considered founded by tribunals than other legal controversies. Likewise, the indicators of the relative strength of parties, such as experience in the international arbitration system, have an important influence on tribunal awards. Furthermore, country's time of experience within ICSID is found to have an important influence on the selection of disputes.
\end{abstract}

Keywords: International investment arbitration; International Center for Settlement of Investment Disputes; Selection theory; Party capability theory.

JEL Classification: F21, K41, F55, C21

a Department of Economics, Pontifical Catholic University of Peru.Email: gruiz@pucp.edu.pe. Orcid ID: 0000-0001-9972-9181 


\section{Introduction}

In the last few decades, international investment arbitration (IIA) has become an important institution for resolving disputes between states and foreign investors. The increasing trend in the number of controversies solved by international arbitration organisations and the growth in the proportion of states that adhered to this mechanism has attracted the attention of scholars from different disciplines to the study of determinants of tribunal outcomes and the governance of such organisations (Zhang, 2017). Latin American and Caribbean (LAC) countries have been part of this process. During the nineties, a third of these countries adhered to the International Centre for Settlement of Investment Disputes (ICSID) and currently, 31\% of IIA disputes solved by this system consist of cases against LAC countries ${ }^{1}$, with the LAC region having the highest cumulative number of controversies litigated under this organisation ${ }^{2}$. At the same time, LAC countries have substantially increased the number of signed bilateral investment treaties (BIT), from 30 treaties in 1990 to 501 treaties in 2019.

Despite these figures and trends, since the mid-2000s, an intense debate has emerged around the characteristics and functioning of the system, with particular emphasis on the governance characteristics of ICSID. On the one hand, some studies highlight the effects that IIA has exerted on the attraction of foreign investment, and their influence, as a signal of the commitment of states with policies toward fair and non-discriminatory treatment to investors (UNCTAD 2009; Vu 2018). In contrast, critics refer to a lack of transparency of arbitration panels and a "pro-claimant" bias against developing countries, particularly LAC, among others (Fiezzoni 2011; Schultz et al. 2015).

Some authors have partly contested these arguments, referring to the statistical analysis of IIA outcomes. Franck (2009) and Franck and Wylie (2015), for example, concluded that outcomes show that investors and countries win IIA disputes in equal proportions, and when investors have won, they received considerably lower awards than those claimed. However, these conclusions are exclusively based on the analysis of IIA-solved cases, not considering the information provided by settled and discontinued cases, which represent a significant proportion of the total registered cases ${ }^{3}$. Consequently, the results reported by these studies may suffer from selection bias, a phenomenon identified by Priest and Kline (1984) and broadly recognised in the literature ${ }^{4}$. According to these authors, the selection of 
legal disputes is generally a non-random function of the different beliefs of the parties with respect to their probability of success, their respective stakes, and the costs of accessing the legal process.

This study uses information from 161 concluded cases litigated under ICSID corresponding to investments in LAC until 2019, finding evidence on the influence of parties' characteristics, the subject discussed in cases, and characteristics of the tribunal on the arbitration outcomes. Furthermore, we show evidence that supports the hypothesis taken from the literature of party capability (Galanter, 1974), demonstrating that more experienced parties achieve better outcomes than "one shooters".

As well, despite the fact that almost equal number of victories for claimant investors and country respondents are observed, evidence of sample selection bias in outcome indicators of IIA disputes was found, using techniques from the family of models introduced by Heckman (1979), that support the hypothesis that, as adverse outcomes under IIA impose considerable costs on respondent countries in terms of awards and deterioration of governments reputation, their willingness to offer attractive settlements to claimant investors could be a dominant strategy compared to litigation. In this context, cases with a relatively high probability of being awarded in favour of claimants would tend to be not submitted to arbitration, reducing the number of founded cases in IIA tribunals. Therefore, outcome indicators such as the share of founded cases, among others, tend to be downward-biased, and the selection of cases for litigation will not be randomly determined.

This article is organised as follows: the next section addresses the current debate around IIA cases between LAC countries and investors; the third section presents selection theory as an avenue for explaining some regularities observed in the IIA, and the fourth section explains the empirical methodology and results. Finally, some concluding remarks are presented.

\section{The Current Debate Around IIA in LAC Countries}

During the nineties, an important group of LAC countries adhered to ICSID as part of a programme of reforms that sought to attract foreign investment to the region. Figure A.1 (see Appendix A) shows that out of the total of 19 countries $^{5}$, the number of LAC members of ICSID rose from 6 in 1990 to 16 in 2000. IIA organisations, such as ICSID, establish rules and procedures 
for solving and settling controversies between investors and states, arising as a consequence of the violation of a bilateral investment agreement, law, or contract. These rules typically include procedures for the appointment of members of the tribunal, the rights of the parties throughout the procedure, and regulations for settling or discontinuing the process.

The reforms implemented by LAC countries also included an ambitious programme for the signature of bilateral investment treaties (BITs). As shown in Figure A.2 (Appendix A), the total number of signed BITs rose from 30 in 1990 to 362 in 2000 for all LAC countries. Typically, a BIT confers investors with some basic rights, such as fair and equitable treatment, national treatment, protection from expropriations and nationalisations, and free transferability of funds (UNCTAD, 2006).

As mentioned by Guzman (1998), based on a seminal article by Kidland and Prescott (1977), conceptually, these efforts toward a stronger protection of foreign direct investments (FDI) can be conceived as measures adopted by host countries with the aim of avoiding the implementation of time-inconsistent policies. The central idea is that, when host countries cannot commit themselves to maintain a determinate policy toward FDI, their announcements and declared promises will not be credible by the investor community ${ }^{6}$. This lack of credibility can be a consequence of reputational factors, or a country's political instability, among others; which could erode the government's capability of achieving its goals in terms of investment policy. An alternative policy for solving this problem consists of adopting a costly credible commitment, providing a signal to make the market effectively believe that changing the rules in the future will be difficult or will imply that governments must pay a high price for changing the rules. Signing a BIT with the most prominent international sources of FDI and becoming a member of IIA organisations could be part of this costly signal of commitment or a way of "tying the hands" of future governments. Accordingly, the United Nations Conference on Trade and Development (UNCTAD) (2009) and Vu (2018) highlighted the effects of IIA on the attraction of foreign investment and their influence as a signal of commitment of states with policies toward fair and non-discriminatory treatment to investors.

During the nineties, FDI inflows to LAC increased substantially from US\$20 billion per year during the period 1990-1995 to US\$70 billion per year during 1996-2000 (ECLAC, 2006: 10). At the same time, the number 
of disputes registered in ICSID grew significantly (see Figure 1) from zero cases during the 1980 s to 128 cases during the period 1990-2010. In addition, the number of awards (concluded cases) over the same period grew from zero to 66.

Figure 1: Registered and Concluded ICSID Cases against LAC Countries

25

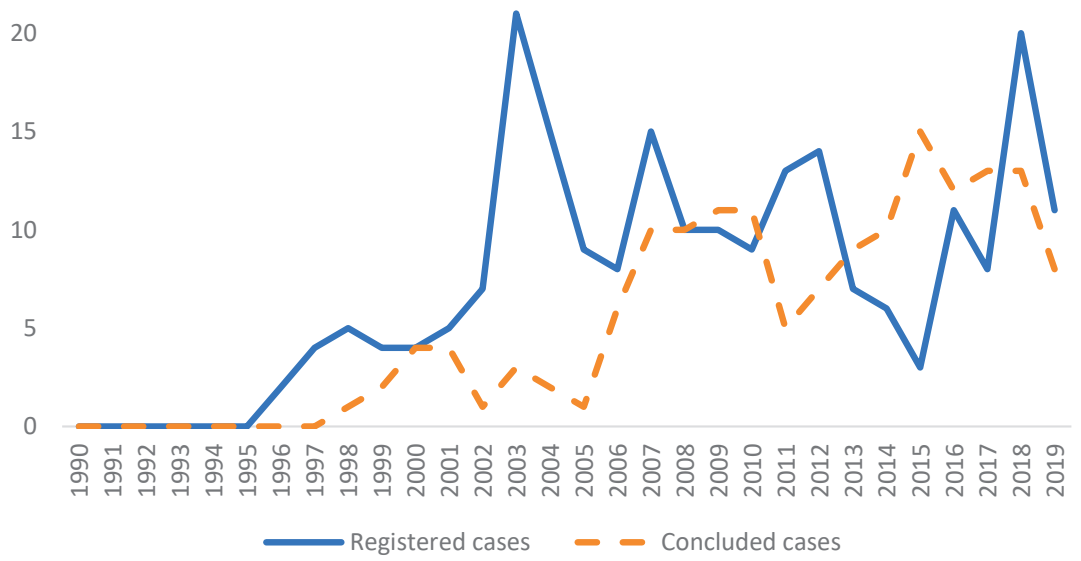

Source: ICSID, elaboration: The author.

However, as mentioned above, during the mid-2000 decade, the criticism of some LAC governments on the functioning of ICSID led to Bolivia's denunciation of this organisation. In April 2007, Evo Morales announced that 'Alba Countries' would decide to retire from ICSID, because investors that recur to that system "do not seek to solve problems through negotiations, because they know that ICSID will decide in their favor" "Three years later, in 2010, Ecuador also denunciated the ICSID Convention. Finally, in 2012, 19 years after its adhesion to ICSID, Venezuela also denounced the convention. These decisions coincided partly with the increase in the number of claims from foreign investors against these countries before the ICSID ${ }^{8}$ and the perception of the government of these countries that this organisation lacked impartiality.

Likewise, several authors have associated these decisions with a crisis of legitimacy of the IIA system. The main criticisms were related 
to the inconsistency of tribunal pronouncements related to similar facts (Franck, 2005; Fiezzoni, 2011), lack of impartiality and biased arbitrators (Van Harten, 2012; Wu et al., 2017; Shultz et al., 2015), and a lack of transparency (Choudhury, 2008). These criticisms have remained, despite the amendments and adjustments introduced in 2006 to ICSID procedures toward increasing transparency and impartiality related to publishing legal excerpts of the awards and strengthening the disclosure requirements for arbitrators (Yackee and Wong, 2011).

In this context, a group of member countries of the Union of South American Nations (UNASUR) has been discussing alternatives to ICSID (Fiezzoni, 2011) as a fora for solving disputes between states and foreign investors. Other alternatives under discussion are the creation of an appeal body for IIA tribunal resolutions (Butler, 2018).

However, some authors have contested critics regarding the lack of impartiality through the use of information on IIA outcomes. Franck (2009) suggested the absence of a pro-investor bias against countries, showing that respondent governments won more often than investors. A similar result with more updated data was found by Franck and Wylie (2015) with the same conclusions. Sweet and Grisel (2017) found evidence that states won more often than investors. Wellhausen (2016) using a data set of 676 cases corresponding to disputes processed at ICSID and United Nations Commission on International Trade Law (UNCITRAL), found that a $37.7 \%$ of cases were favourable to respondent countries, $29.1 \%$ to investors while settlements $33.1 \%$. However, when considering only the region Americas, the countries' ratio of wins reduces to $31.8 \%$.

Other outcome indicators, such as the percentage of the claimant's economic pretension awarded by IIA tribunals, have also been mentioned as evidence of the absence of pro-investor bias. Franck (2009) found that while on average, claimants' damages have been US\$343 million, the average awarded result is approximately only US $\$ 10$ million, that is, an "investor success ratio" of 2.9\%. Franck and Wylie (2015) found a substantially higher ratio of $35 \%$.

However, using the data on outcomes could be misleading. The articles and reports mentioned above recognise that the number of cases discontinued, or settled, represents approximately one-third of the total IIA cases concluded. If parties opted for litigation, these cases would change the average of the outcome indicators. The party's decisions of not litigating are 
related to their expectations of winning or losing, the costs of the litigation, and the foreseen amounts of awards.

Reviewing the data of the outcomes of concluded cases for LAC countries for this study, we found that, of the 161 cases assessed, a total of 107 were submitted to arbitration. The remaining 54 cases $(33.5 \%$ of the total) were settled or discontinued. From the 107 cases, 54 were declared totally or partially founded, representing $50.5 \%$ of the total litigated cases, a result similar to that found in other studies (see Table B.1.). Furthermore, claimant pretensions and awards in the founded cases are shown in Table B.2. The average pretension in these cases was US\$448.1, and the average award as a percentage of the claimant's pretension was $44.6 \%$.

It is important to note that both outcome indicators have different implications for the analysis. While founded/unfounded indicators bring a general signal to the market about a party's victory, having a reputational effect particularly in host countries or investors "repeat players"; indicators of awards as a percentage of claimants' pretensions (which can include those cases declared unfounded by the tribunal) can measure the relative success of parties with respect to the diverse claims and arguments exposed during the process.

As we will see below, these outcome indicators may suffer of sample selection bias. The direction and magnitude of such bias will depend on the cost of litigation, the party's belief about success, and their respective stakes.

\section{Selection Theory, Party Capability and International Arbitration}

The conceptual framework to be used as the base of our methodology relies mainly on selection and party capability theories. In this section, we briefly describe the foundations of both theories and its application to IIA.

\subsection{Selection theory}

As in any legal dispute, IIA controversies can be conceived as the result of a failure of the parties to reach an agreement. According to Priest and Klein (1984), this situation occurs when the pretension of the claimant exceeds the maximum amount that the respondent is disposed to offer to avoid being sued, minus their respective costs of litigation: 


$$
P_{c} J_{c}-P_{R} J_{R}-\left(C_{c}-C_{R}\right)>0
$$

In the above expression, $P_{i}$ is the belief or probability that the party assigns to a founded award, where subindex $C$ corresponds to claimant (or plaintiff), and $R$ denotes the respondent (or defendant). In addition, $J_{i}$ denotes the expected outcome and the effect of the legal process (stakes), while $C_{i}$ is the perceived cost of litigation for party $i$. Stakes consist of either the respondent's estimated loss or claimant expected award. Whether respondent and claimant stakes were equal, disputes could be conceived as zero-sum games. However, as we will see below, this is not the case of IIA dispute.

According to this expression described above, a litigation will arise whenever the claimant's expected outcomes (i.e., the expected award multiplied by its estimated probability) minus their perceived legal costs is higher than the expected outcomes from the defendant's perspective (and the potential settlement offer) plus their litigation costs. It is important to observe that probabilities estimated by the parties may differ depending on their characteristics, legal experience, and capabilities of processing information, among others. In addition, stakes can be perceived differently by parties. Certainly, in some cases, the most important component of the stake will consist of the amount of the award decided by the tribunal. However, for some litigants, legal outcomes not only involve a pecuniary contingency but can also have a negative effect on their reputation. According to Gallanter's (1974) party capability theory, some litigants can be considered as "repeat players," in the sense that they are characterised by their recurrent participation in legal disputes. In these cases, the reputational implications of legal outcomes are an important component of their stakes.

Rearranging the expression, we obtain the following inequality:

$$
P_{C}-P_{R}>\frac{C}{\bar{J}}+\bar{P} \frac{\Delta J}{\bar{J}}
$$

where $\bar{J}=\frac{J_{C}+J_{R}}{2}, \bar{P}=\frac{P_{C}+P_{R}}{2}, C=C_{C}+C_{R}$, and $\Delta J=J_{R}-J_{C}$. From this expression, two important results can be inferred. First, in the presence of positive costs of litigation or situations where respondents' stakes are higher than those corresponding to the defendant $(\Delta J>0)$, the selection of disputes requires relatively high differences between the beliefs of claimants and respondents. One important implication of this result is that when a 
respondent's stakes exceed those corresponding to the claimant, the rate of disputes submitted for arbitration decreases. In the presence of a high expected compensation imposed by tribunals, respondent countries will have strong incentives to present higher settlement offers to claimants. Furthermore, when the difference between the stakes of the respondent and claimant is small or negative, the rate of litigation or selection would tend to increase. In this case, relatively low differences in the beliefs of both parties (given the reasonably low levels of $C$ ) will be sufficient to create a legal dispute.

Applying this result to the context of the IIA, claimants' stakes can typically be represented by the investors' pretension of economic relief or compensation presented under an arbitration tribunal. However, for governments of host countries, which can be considered "repeat players", stakes will be represented not only by the direct economic obligation imposed through an adverse award of the tribunal but also by the reputational effects of this outcome. A founded verdict in an arbitration case can negatively affect the external image of a government and the international investor community's perception of the country's conditions as a potential destination for foreign investments. These higher stakes involved for host countries, compared to those for investors $(\Delta J>0)$ could explain the relatively high rates of settlements and discontinued cases observed in the IIA. It is important to note, as we will see below, that this difference between stakes can be attenuated in the presence of some investors who have participated in various international disputes, that can also be characterised as "repeat players" in contrast with occasional litigants denoted by the literature as "one shooters".

Other applications of this result to IIA relate to the differences in beliefs between parties. Direct expropriation cases are often objectively demonstrable, and, by definition, less controversial measures against investors typically do not have high differences in "rational' parties" beliefs about the probable outcome of an arbitration case. Thus, it is expected that in these cases, the rate of selection will tend to decrease. In addition, governments will be incentivised to present more attractive settlement offers, given the reduced probability of receiving a favourable award. On the contrary, in less clear cases, where uncertainty about the outcome of the legal process is greater, for example, when allegations refer to indirect expropriation measures or fair and equitable treatment, litigation rates would tend to be relatively high. 
The second observation relates to the implications of the analysis presented above regarding the party's rate of victory in litigation. If we consider the average party's estimated probabilities as a reasonable indicator of their likelihood of success ${ }^{9}$, high levels of $\bar{P}$ can be associated with high rates of claimant victories. However, this only will occur if the dispute is selected, particularly when $\Delta J$ is low or negative. Thus, as claimants' stakes exceed those of respondents, and litigation arises, more plaintiff victories will be observed. Conversely, for positive levels of $\Delta J$, when a dispute is selected, high rates of defendant's victories will be observed, given that selection will occur only for low levels of $\bar{P}$.

As suggested above, in the context of IIA, the host country's stakes are typically higher than those corresponding to investors. This is a consequence of the fact that host countries are "repeat players" in the IIA system, and consequently, adverse outcomes will have a reputational effect. As mentioned above, in contrast with private arbitration games (with 'one-shot players' as parties), which can be characterised as a zero-sum game, the IIA is generally a negative or positive sum game depending on the impact of the outcome on a country's reputation.

In this context, under clear arbitrary measures or direct expropriations, as mentioned above, low rates of litigation will be observed, however, when selected, disputes will tend to be favourable to respondents because of the low levels of $\bar{P}$. A salient example of a settled case, which involved a nationalisation was the expropriation of the $51 \%$ of shares of Repsol (a Spaniard gas and oil company) by the Argentinean government, that concluded in a settlement with an indemnification of US\$5,000 million. On the other side, the example of the direct expropriation of two glass manufacturing plants by the Venezuelan government, which involved significantly a lower economic pretension, was finally litigated, and awarded to the claimant, Owen Illinois European Group BV by US\$372.5 million.

As adverse outcomes under the IIA impose considerable costs on respondent countries in terms of awards and deterioration of their reputation, their willingness to offer attractive settlements to claimant investors could be a dominant strategy compared to litigation. In this context, cases with a relatively high probability of being awarded in favour of investors would tend to be settled or discontinued, reducing the number of founded cases in IIA tribunals. Thus, indicators such as the share of founded cases will tend to be downward-biased. 
To our knowledge, selection bias has received little attention in international arbitration literature. Strezhnev (2017) attempted to explain the evidence in favour of pro-rich countries' biases in IIA, modelling the behaviour of respondent countries and claimant investors as a function of their capacity of litigation and the existence of informational asymmetries between parties. According to his analysis, low-capacity states will be more prone to offer settlements, however, to the extent that they cannot directly observe the "quality" of claimant, only weak investors will accept such offers. This would explain why trial awards tend to favour more often rich countries instead of poor. This analysis however omits the important role that stakes play in selection and does not offer a convincing explanation for the assumption of informational asymmetries.

In a recent article, $\mathrm{Vu}$ (2020) studied the determinants of settlements in the context of IIA. However, while confirming the non-random nature of selection of disputes in IIA, no causal relation is inferred with respect of tribunal's outcomes.

\subsection{Party capability theory}

According to the theory of party capability (Galanter, 1974), the characteristics of the parties are factors that contribute to explain the outcome of the legal disputes. Parties involved in legal disputes can be categorised as "repeat players" (RPs) or "one shotters" (OSs). A RP is a party that participates in many trials over time, whereas an OS only participates occasionally. Accordingly, RPs consider the outcome of a specific trial as a small component of a broad portfolio of disputes, while for OSs, the stakes involved in a dispute may represent a high proportion of their wealth.

Typically, a RP can be characterised as a party which has access to specialists and exhibit economies of scale that allow them to "invest" in lawyers and specialists. This allows them, among others, to use more effective arguments to influence tribunal decisions. To the extent that RPs face many rivals over time, the reputational effect of tribunal outcomes are important. In contrast, for an OS, litigation is a one-period game. In the context of IIA, typically respondent countries can be considered RP, to the extent that they can be subject to a number of arbitration demands and tribunal decisions may have important reputational effects. As well, 
transnational companies which are exposed to regulatory risks in several countries, and face arbitration disputes in several jurisdictions, can also be categorised as a RP. It would be expected that such transnational companies perform better in IIA than OS claimants.

According to capability theory, in cases in which parties with different degrees of strength interact, the share of the claimants' victories at trial will depend on its relative participation. The issue of heterogeneity complicates their analysis because some advantages and disadvantages may exist simultaneously for the claimants and respondents, making the probable net effect success rate at trial less clear.

Party capability theory has been used mainly for the evaluation of the performance of supreme court appeals processes in developed countries ${ }^{10}$, and the general results support Galanter's theory. Applications to IIA are almost inexistent with the only exception of Franck and Wylie (2015).

\section{Methodology}

As mentioned above, the empirical analysis was applied to 161 concluded cases $^{11}$ accessed from the ICSID database ${ }^{12}$, corresponding to investments in 18 LAC countries. Secondary sources, such as UNCTAD ${ }^{13}$ and Italaw ${ }^{14}$, were used.

From a total of 161 cases, only 107 were submitted to arbitration. The remaining 54 cases were discontinued, based on ICSID rules, or settled. The ICSID Convention regulates the termination originated from a mutual consent between parties (Article 43) at the request of one of the parties (Article 44) or the abandonment of the case (Article 45). As shown in Table B.1, cases won by the claimant, defined as those in which the tribunal award either partially or totally accepts the plaintiff's pretensions, represented approximately half $(50.4 \%)$ of the total litigated cases. These cases are identified with the binary variable founded, which adopts a value of 1 for claimant victories and 0 otherwise.

Other measures used for characterising tribunals' decisions consist of the ratio of the award of the tribunal divided by the claimant's economic compensation or relief requested. This variable, which takes a value between 0 and 1 , is denoted as awardstake ${ }_{i}$

Both founded $_{i}$ and awardstake $_{i}$ are different measures of the outcome (O) of IIA. Variables that influence the outcome of the arbitral process can be 
grouped among those related to parties' characteristics $(P)$, subject discussed in case $(C)$, and characteristics of the tribunal $(T)$ :

$$
O=f(P, C, T)
$$

A first variable proposed for characterising investors in vector $P$, according to party capability theory, consists of the number of cases litigated under the ICSID, denoted by Numcaseclai ${ }_{i}$. While some investors with presence and legal disputes in various countries can be considered as "repeat players," the majority can be considered as "one-shot" players. Indeed, 70\% of the total cases analysed correspond to investors whose names appears only once in the ICSID database. It is expected that more experienced investors can achieve relatively better results than "one-shot" players.

In the case of host countries, the proxy used consists of the number of years elapsed since the signature of ICSID and the date of registration of the case (tesinceicsid $)_{i}{ }^{15}$. The thesis is that the longer the experience of the country inside the ICSID forum, the stronger its capabilities as a litigant.

It is expected that the business environment and regulatory policies may influence IIA outcomes. To characterise the investment environment of the host country, after the assessment of variables ${ }^{16}$ taken from the Worldwide Governance International (Kauffman et al., 2010), the variable geffect $_{i}$ is used to denote the level of government effectiveness of the host country during the year of registration of the controversy at ICSID.

Other attributes of host countries discussed in the literature relate to their level of development (Franck, 2009). In these cases, we used the GDP per capita $(\operatorname{Lgdppc})$ of the country on the date of registration of the demand as a proxy for the development status. This variable was expressed in dollars of 2019 and transformed to logarithms for reducing the variability between countries.

With respect to the case characteristics (vector $C$ ), to test the selection theory hypothesis, we consider a variable Lstaker $_{i}$, which is the amount of compensation claimed by the investor. As in the case of $\operatorname{Lgdppc}_{i}$, the variable was expressed in 2019 dollars and then transformed to logarithms. As mentioned above, a country's stakes in legal disputes are not only related to the economic amount claimed by the investor but also to the reputational effects of an adverse verdict. Despite the abovementioned, it is plausible to assume that this reputational effect on the host country can be a direct 
function of the economic claim of the investor. The magnitude of the amount claimed can be proportional to the impact of the case in public media and the perception of the international community of investors. Considering that this proportion equals to $\alpha$, and that the claimant's stake (denoted by $S$ ) can be represented by the economic pretension requested under the tribunal, $\Delta J$, as described by Priest and Klein (1982), is equal to $(1+\alpha) S-S=\alpha S$.

In addition, we distinguish between cases in which the investor's claim refers to a direct expropriation from other allegations, using qualitative variable Dexprop $_{i}$. Direct expropriation refers to measures adopted by host countries against investors, limiting or violating their property rights. Examples of such measures are nationalisations, the physical seizure of assets, or the forced transfer of assets to the state. Transgression of other rights, identified under the label of "indirect expropriation" refers to losses caused to investors by governmental actions or regulations that diminish the value of or the revenue from their investment (Barklem and Prieto-Ríos 2011).

To consider the hypothesis on the influence of tribunal preferences (vector $T$ ) in awards (Waibel and Wu, 2017; Van Harten, 2012; Franck, 2009) regarding the bias or inclinations of arbitrators, which are nationals of host states, we construct a dummy variable denoted by Preslatam $i$, which identifies those cases where the president of the tribunal is a national of a LAC country.

According to our methodology, we propose determinants not only of outcomes but also of the selection of cases for litigation. Among the determinants of case selection (described by binary variable selected ${ }_{i}$ ), Lstaker $_{i}$ was also considered as a variable that reduces selection (as a proxy of respondent stakes). In addition, according to the selection theory, Dexprop is expected to have a negative effect on selection to the extent that host countries will be incentivised to offer settlements to avoid litigation. Other determinants considered were the economic sector where disputes arose. After a correlation analysis, we select those cases that belong to electrical services, information, and finance through variable Infinel ${ }_{i}$, which has shown a negative relationship with selected ${ }_{i}$. This specification coincides partially, with $\mathrm{Vu}$ (2020) who estimated the determinants of settlements in IIA. This author, used a different proxy regarding the subject of the dispute, including direct expropriation in a broader group of measures, denoted "extreme" regulations. 
With the aim of testing the hypothesis related to IIA outcomes and selection, we use two alternative estimation models. The first one is a probit model that measures the outcome of the arbitration process as a binary variable (founded/unfounded). The second is a fractional response model wherein the variable of interest consists of the proportion of the claimant pretension awarded by the tribunal, a variable located inside interval $[0,1]$.

\section{Results}

The results of both models without the correction of sample selection are shown in Table 1. Table 1 presents the results of the probit estimations of found (first column), selected (third column), and fractional response estimation of awardstake $_{i}$ (second column). Chi-square statistics show that in the case of the three estimations, the null hypothesis of non-joint significance is rejected.

Table 1: Probit and Fractional Response Model Estimations without Correction of Sample Selection

\begin{tabular}{|c|c|c|c|}
\hline & $\begin{array}{r}\text { Founded }_{i} \\
\text { Probit }\end{array}$ & $\begin{array}{r}\text { Awardstake }_{i} \\
\text { Fractional } \\
\text { Response }\end{array}$ & $\begin{array}{r}\text { Selected }_{i} \\
\text { (Probit) }\end{array}$ \\
\hline Lstaker $_{i}$ & $\begin{array}{r}0.04 \\
(0.09)\end{array}$ & $\begin{array}{l}-0.15 * * \\
(0.07)\end{array}$ & $\begin{array}{l}-0.14 * * \\
(0.07)\end{array}$ \\
\hline Dexprop $_{i}$ & $\begin{array}{l}0.99^{* * *} \\
(0.31)\end{array}$ & $\begin{array}{l}0.57 * * * \\
(0.21)\end{array}$ & $\begin{array}{c}-0.33 \\
(0.23)\end{array}$ \\
\hline Tesinceicsid $_{i}$ & $\begin{array}{l}-0.10 * * * \\
(0.03)\end{array}$ & $\begin{array}{l}-0.05 * * * \\
(0.02)\end{array}$ & $\cdots$ \\
\hline Preslatam $_{i}$ & $\begin{array}{l}-0.80 * * \\
(0.33)\end{array}$ & $\begin{array}{c}-0.38 \\
(0.24)\end{array}$ & $\ldots$ \\
\hline Numcaseclai $_{i}$ & $\begin{array}{l}0.47 * * \\
(0.23)\end{array}$ & $\begin{array}{l}0.41 \text { *** } \\
(0.09)\end{array}$ & $\begin{array}{l}-0.23 * * \\
(0.10)\end{array}$ \\
\hline Infinel $_{i}$ & $\ldots$ & $\ldots$ & $\begin{array}{l}-0.81 \text { *** } \\
(0.24)\end{array}$ \\
\hline Geffect $_{i}$ & $\ldots$ & $\begin{array}{l}-0.27 \\
(0.16)\end{array}$ & $\ldots$ \\
\hline$L g d p p c_{i}$ & $\ldots$ & $\begin{array}{l}-0.18 \\
(0.28)\end{array}$ & $\ldots$ \\
\hline Constant & $\begin{array}{r}0.32 \\
(0.61)\end{array}$ & $\begin{array}{r}1.44 \\
(2.45)\end{array}$ & $\begin{array}{l}1.86 * * * \\
(0.42)\end{array}$ \\
\hline
\end{tabular}




\begin{tabular}{|c|c|c|c|}
\hline & $\begin{array}{r}\text { Founded }_{i} \\
\text { Probit }^{2}\end{array}$ & $\begin{array}{r}\text { Awardstake }_{i} \\
\text { Fractional } \\
\text { Response }\end{array}$ & $\begin{array}{r}\text { Selected }_{i} \\
\text { (Probit) }\end{array}$ \\
\hline$N$ & 107 & 107 & 161 \\
\hline Chi Square $1 /$. & $36.98 * * *$ & $48.87 * * *$ & $21.55 * * *$ \\
\hline Log Likelihood & -55.7 & $-46.6^{2 /}$ & -91.9 \\
\hline
\end{tabular}

Notes: $* * * 1 \%$ of significance, $* * 5 \%$ of significance and $* 10 \%$ of significance. Standard deviation is reported in parenthesis.

1/. For probit estimations, calculations correspond to Likelihood Ratio tests, while for fractional response model calculations corresponds to Wald test.

2/. Pseudo-likelihood.

As shown in the first column of Table 1, variables related to litigants' characteristics and the party capability theory (Tesinceicsid ${ }_{i}$, Numcasecla ${ }_{i i}$ ) are statistically significant and exhibit the expected sign. Variables related to case characteristics such as Dexprop ${ }_{i}$ are significant and according to the theory of selection, show a positive sign: direct expropriation cases are more likely to be declared as founded. In addition, the hypothesis related to the influence of arbitrators' characteristics on awards seems to be corroborated, suggesting that tribunals presided by nationals from LAC countries generally tend to decide in favour of host countries.

The second column shows that variables related to litigants' characteristics also have a statistically significant impact on the second indicator of arbitration outcome: Awardstake . Similarly, Dexprop $_{i}$ was found to be statistically significant, with the expected sign. In this case, Lstaker $_{i}$ was found to be significant and with the expected sign: the higher the respondent's stake, the greater the probability of achieving a favourable verdict. In the case of Preslatam $i$, unlike the results observed for founded, no statistical evidence could be verified. Likewise, no significant statistical relationship was found for respondents' characteristics, such as government effectiveness ( geffect $\left._{i}\right)$ and level of development $\left(L g d p p c_{i}\right)$.

Finally, as the selection theory predicts, the selection equation shows that selection is inversely related to the respondent's stakes indicator (Lstaker ${ }_{i}$. In addition, the estimation shows that proxies of the claimant's strength, such as Numcasecla ${ }_{i}^{i}$, relate negatively to selection. This indicates that more informed and experienced claimants tend to be more prone to settle or discontinue their demands than weaker litigants. Furthermore, 
sectoral characteristics have a statistical influence on case selection. Indeed, demands related to information, financial and electrical projects are less likely to end in an arbitration process.

\section{Estimations with selection}

As mentioned in previous sections, the average indicators of the IIA's outcome processes could be biased if the analysis of settled or discontinued cases is omitted. As the selection theory states, respondents and claimants will decide not to settle or discontinue the demand, depending on their beliefs about the expected outcome, the expected costs of the arbitration process, and their respective amount of stake. For example, if respondents' beliefs of success are low or their stakes are high enough, the probability of them offering an attractive settlement to the claimant will rise.

The estimation methods used for selection models belong to the family of techniques introduced by Heckman (1979). The econometric methods used are maximum likelihood, where in the case of founded $_{i}$, a dichotomous variable, the principal, and the selection equation consist of probit models (Lokshin and Sajaja 2011).

It is important to mention that Heckman (1979) method for correcting selection bias is superior to others used in international arbitration literature. For example, Behn et al. (2018) used ad hoc methods by analysing some settlements results for inferring which of the parties won or lose. This strategy faces at least three shortcomings. The first and most obvious is that it excludes the dismissed cases (when the claimant unilaterally discontinues the process). The second is that the criteria for qualifying a party's victory could be always debatable and subject to the criteria and discretion of the researcher. The third is that the agreements reached through settlement processes may be guided by reasons or factors different from those considered by trials for justifying an award.

In the case of awardstake, which is a continuous variable in the interval $[0,1]$, the model for the principal equation is estimated through a fractional response model, and for the selection equation a probit specification was used. Following Roodman (2011), the estimation was performed using a mixed-process model. 
Table 2 shows the results of selection models estimation. Both models exhibit high levels of joint significance. In both cases, the test of no presence of bias selection ( rho $=0$ ) was rejected, evidencing the importance of information provided by settled and discontinued cases in the explanation of IIA's outcomes.

Table 2: Probit and Fractional Response Models Estimations with Selection

\begin{tabular}{|c|c|c|c|c|}
\hline & $\begin{array}{r}\text { Founded }_{i} \\
\text { Probit }\end{array}$ & $\begin{array}{r}\text { Selected }_{i} \\
\text { (Probit) }\end{array}$ & $\begin{array}{r}\text { Awardstake }_{i} \\
\text { Fractional } \\
\text { Response }\end{array}$ & $\begin{array}{r}\text { Selected }_{i} \\
\text { (Probit) }\end{array}$ \\
\hline \multirow[t]{2}{*}{ Lstaker $_{i}$} & $0.12 *$ & $-0.14 * *$ & -0.04 & $-0.13 * *$ \\
\hline & $(0.07)$ & $(0.06)$ & $(0.07)$ & $(0.06)$ \\
\hline \multirow{2}{*}{ Dexprop $_{i}$} & $0.81 * * *$ & -0.34 & $0.48 * *$ & -0.34 \\
\hline & $(0.26)$ & $(0.23)$ & $(0.22)$ & $(0.23)$ \\
\hline \multirow[t]{2}{*}{ Tesinceicsid $_{i}$} & $-0.08 * * *$ & $\ldots$ & $-0.05 * * *$ & $\ldots$ \\
\hline & $(0.02)$ & & $(0.01)$ & \\
\hline \multirow{2}{*}{ Preslatam $_{i}$} & $-0.45 * *$ & $\ldots$ & -0.22 & $\ldots$ \\
\hline & $(0.19)$ & & $(0.18)$ & \\
\hline \multirow[t]{2}{*}{ Numcaseclai $_{i}$} & $0.53 * * *$ & $-0.22 * *$ & $0.42 * * *$ & $-0.23 * *$ \\
\hline & $(0.2)$ & $(0.10)$ & $(0.10)$ & $(0.10)$ \\
\hline \multirow[t]{2}{*}{ Infinel $_{i}$} & $\ldots$ & $-0.89 * * *$ & $\ldots$ & $-0.83 * * *$ \\
\hline & & $(0.22)$ & & $(0.23)$ \\
\hline \multirow[t]{2}{*}{ Geffect $_{i}$} & $\cdots$ & $\ldots$ & $-0.25 * *$ & $\ldots$ \\
\hline & & & $(0.12)$ & \\
\hline \multirow[t]{2}{*}{$\operatorname{Lgppc}_{i}$} & $\ldots$ & $\ldots$ & -0.17 & $\cdots$ \\
\hline & & & $(0.20)$ & \\
\hline \multirow[t]{2}{*}{ Constant } & 0.02 & $1.84 * * *$ & 1.28 & $1.82 * * *$ \\
\hline & $(0.52)$ & $(0.4)$ & (1.77) & $(0.42)$ \\
\hline$N$ & 161 & & 161 & \\
\hline Chi Square ${ }^{1 /}$ & 69.0 & $* * *$ & 36.8 & $* * *$ \\
\hline Log Likelihood & -144.7 & & -137.3 & $2 \%$ \\
\hline Chi Sq $(\text { rho }=0)^{1 /}$ & 5.8 & $* *$ & 3.9 & $* *$ \\
\hline
\end{tabular}

Notes: $* * * 1 \%$ of significance, $* * 5 \%$ of significance and $* 10 \%$ of significance. Standard deviation reported in parenthesis.

1/. For probit estimations calculations corresponds to Likelihood Ratio tests, while for fractional response model calculations corresponds to Wald test.

2/. Pseudo-likelihood 
The first two columns show the results of the selection model for founded $_{i}$. In general terms, the results obtained (signs and significance levels) from the estimation of models without selection are confirmed. While the majority of estimated parameters show small variations with respect to the model without selection, it can be observed that the parameter of Preslatam reduces significantly and Dexprop $_{i}$ also shows a reduction. This observation means that once the selection bias is corrected, the effect of "pro-respondent" arbitrators on tribunal decisions reduces significantly and the likelihood of an unfounded verdict diminishes.

In the case of the second model, some determinants of awardstake $_{i}$ loss and others gain significance, compared to the model without correction for bias selection. Indeed, Lstaker $_{i}$ loses significance and, in contrast, geffect $_{i}$ acquires significance. In the case of this last variable, the results show that countries whose governments are qualified as "effective," reduce their risk of receiving adverse awards in terms of compensation obligations to their legal counterparts. As in the case of the binary variable founded $_{i}$ model, Dexprop $p_{i}$ reduces its influence on the outcome of the IIA process.

To inquire about the direction of the bias detected in the estimations of founded $_{i}$ and awardstake $_{i}$, I compare the mean of the estimated values in equations with and without correction for selection bias (see Table 3). In the first case, the average for estimation of founded $_{i}$ without selection correction was 0.51 , whereas in the second case, the average was 0.66 . In the case of awardstake $_{i}$, the average of the estimated values without selection correction was 0.22 , while in the case with selection correction it was $0.31^{17}$. This result supports the hypothesis that the outcome results suffer from selection bias. This bias originates from the nature of IIA disputes, where respondents' stakes generally tend to be higher than those of investor claimants. Indeed, reputational costs of adverse verdicts lead respondent countries to increase their willingness to offer attractive settlements to investors, instead of facing the risk of a plausible unfavourable award. If those cases were included, the average outcome of IIA awards will tend to reflect a higher share of the claimant's victories. These results were corroborated through the implementation of t-test of means, rejecting in both cases the null hypothesis of mean equality, in favour of the alternative hypothesis of downward biased results: 
Table 3. Mean T-test on Predicted Outcomes

\begin{tabular}{lccc}
\hline & $\mathbf{( 1 )}$ & $\mathbf{( 2 )}$ \\
& Without Selection & With Selection & \\
\hline founded & 0.5063951 & 0.6579625 & \\
& $(0.026)$ & $(0.018)$ & $* * *$ \\
awardstake & $H_{0}:(1)-(2)=0$ versus $H_{A}:(1)-(2)<0$ & \\
& 0.2211199 & 0.308505 & $(0.01)$ \\
& $(0.017)$ & $* * *$ \\
\hline
\end{tabular}

Notes: $* * * 1 \%$ of significance, $* * 5 \%$ of significance and $* 10 \%$ of significance. Standard deviation is reported in parenthesis.

Table 4 allows us to characterise a bit more the results, using data take partially from Table B.3 (Appendix B). As can be seen, a 30.4\% of the total cases registered under the ICSID (161) corresponds to claims related to direct expropriation. However, from the total of unselected cases, the share of those related to direct expropriation is higher (35.2\%) compared to cases related to other topics $(28.0 \%)$. As the beliefs regarding a possible founded verdict are high, being the cases of direct expropriation particularly sensitive, respondents' countries will be incentivised to seek solutions without litigation. Accordingly, to the extent that country's stakes grow, the most plausible result would be non-selection. Furthermore, we can observe that the share of not selected cases for Infinel $_{i}$ is also lower compared with not selected cases.

Table 4: Share of Selected and Unselected Cases for Selected Variables

\begin{tabular}{lllll}
\hline & Dexprop $_{\boldsymbol{i}}$ & Lstaker $_{\boldsymbol{i}}$ & ArgBoVenEcu $_{\boldsymbol{i}}$ & Infinel $_{\boldsymbol{i}}$ \\
\hline Not Selected & $35.2 \%$ & 5.59 & $74.1 \%$ & $42.6 \%$ \\
Selected & $28.0 \%$ & 4.93 & $48.6 \%$ & $19.6 \%$ \\
Total & $30.4 \%$ & 5.15 & $57.1 \%$ & $27.3 \%$ \\
\hline
\end{tabular}

Finally, we show cases corresponding to Argentina, Bolivia, Venezuela, and Ecuador-countries whose governments during mid-2000s have either abandoned the ICSID or have received a relatively high proportion of unfavourable awards ${ }^{18}$. As can be seen, the share of unselected cases 
in these countries is significantly higher than that of selected cases. A plausible explanation for this result is that for a high proportion of cases, the government's beliefs of obtaining an adverse verdict have been high enough; hence a dominant strategy for these countries has been to seek alternatives of settlement or others that lead to non-selection.

\section{Concluding Remarks}

The findings confirm that relying exclusively on trial outcome indicators for assessing or inferring bias toward respondents or claimants could be misleading. In particular, the results suggest that not considering the characteristics of selection processes in the analysis could lead to an underestimation of the share of adverse outcomes for host countries.

The results also corroborate hypothesis taken from the literature regarding the influence of the case subject, tribunal composition and party's characteristics on IIA tribunals outcomes. Indeed, direct expropriation cases and electrical services, information, and finance disputes show a higher likelihood of being awarded in favour of claimant investors. Furthermore, as literature recognises, tribunal outcomes are strongly correlated with arbitrators' preferences, which are influenced by its country or region of origin. Finally, indicators of either respondent or claimant experience in IIA showed to be relevant determinants of tribunal outcomes. Certainly, as mentioned in Section 2, the literature has identified some failures related to inconsistencies in IIA tribunal pronouncements, lack of transparency in procedures, or a low degree of impartiality of arbitrators that deserve attention and must be part of the future reform agenda of the ICSID.

Even when ICSID concentrates the major volume of IIA cases between investors and LAC, not including other arbitration centres like the UNCITRAL could be considered a limitation of this study. However, restricting the analysis to ICSID could have the advantage of focusing on the organisation that has been at the centre of the debate and the target of the most severe criticism from scholars and LAC countries representatives. For this reason, as well, the election of only LAC countries as the subject of analysis relies in the objective of focus this analysis only in pro-investor biases; excluding other interesting topics studied by the literature as the prorich country bias of IIA decisions. 
On the other side, it is important to differentiate among the relative performance of LAC countries under the IIA system. This performance can be evaluated in terms of the effectiveness of policies oriented to the attraction of FDI (since the year of adherence to the ICSID) versus the risks or costs related to litigation activity. FDI can be considered as a rough proxy of the country's benefit of adherence to the IIA system as well as of the signature of BITs with the main capital and investment exporters. This variable is represented in the vertical axis of Figure 2 and is expressed in logarithms.

Figure 2: FDI versus Number of Disputes Registered Under ICSID

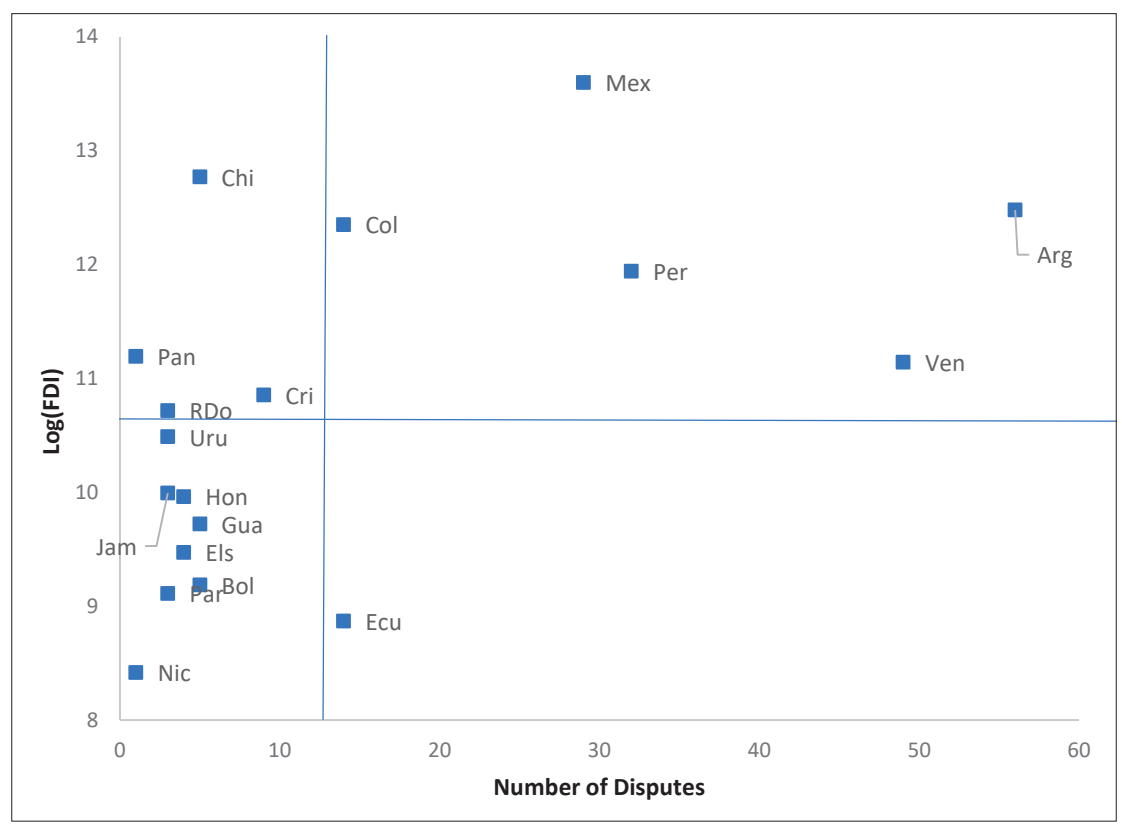

Source: IMF and ICSID.

The main costs faced by countries associated with their adherence to international instruments of protection of FDI are the reduced flexibility in their internal policies aligned with their international commitments and the increased exposure to international litigation. A proxy for this exposure could be the number of disputes registered under ICSID ${ }^{19}$. 
According to Figure 2, the countries' performance shows a considerable degree of variability. Countries can be classified into four groups. Lines dividing each quadrant correspond to averages of the number registered disputes and $\log (\mathrm{FDI})^{20}$. First, those countries located in the left superior quadrant represent those whose adherence to the IIA system has been associated with high levels of FDI attraction and relatively low costs in terms of international litigation. Countries located in the upper right quadrant are those that have attracted high levels of FDI to their countries; their cost in terms of international litigation has also been relatively high. Countries located in the bottom-left quadrant are those that have neither been exposed to a high number of disputes nor have benefited from higher levels of FDI. Finally, in the bottom-right quadrant (which only includes Ecuador) represents the countries cases with lower benefits in terms of FDI and higher costs in terms of number of disputes. Certainly, part of the variability in FDI observed in Figure 2 could be attributed to a "scale effect," to the extent that bigger markets can naturally attract increased levels of FDI. However, it is interesting to note that even in these countries, there exist heterogeneity between those with a low number of international demands (such as Chile) and those with high levels of international demands (such as Argentina and Venezuela). The reasons for these sharp differences should be found not only in the acknowledged failures of IIA system, but also in the heterogeneous and variable pattern of policies followed by these LAC countries toward FDI.

\section{Notes}

1 According to the ICSID database (see icsid.worldbank.org/cases/ case-database), 255 out of a total of 828 concluded or pending cases correspond to LAC countries.

2 See, for example, figures of ICSID (2017, 2018, and 2019), which show that total case load of South America plus Central America and the Caribbean accounts for approximately $28 \%-29 \%$ of the total case load, followed by East Europe and Asia, which comprise 26\% of the total case load. Note that Mexico is excluded from this proportion, because ICSID includes this country in the North American region.

3 According ICSID (2020), the number of discontinued or settled cases as of 2020 represented $36 \%$ of the total concluded cases. 
4 See, for example, Siegelman and Waldfogel (1999) or Kessler et al. (1996). Some recent studies on the same issue applied to international arbitration have been performed by Vu (2020) or Strezhnev (2017).

5 Including Argentina, Bolivia, Chile, Costa Rica, Colombia, Dominican Republic, Ecuador, El Salvador, Guatemala, Honduras, Jamaica, Mexico, Nicaragua, Panama, Paraguay, Peru, Trinidad and Tobago, Uruguay, and Venezuela.

6 Tobin and Rose-Ackerman (2011) studied the impact of bilateral investment treaties on FDI in developing countries.

7 See www.cooperativa.cl/noticias/mundo/bolivia/evo-morales/ evo-morales-anuncio-que-paises-del-alba-se-retiran-delciadi/2007-04-29/173105.html (accessed February 7, 2021).

8 Venezuela had a cumulative number of 20 cases, Ecuador had 11, and Bolivia, 3, before these countries denounced the ICSID Convention.

9 Priest and Klein (1984) assumed that parties behave according to the "rational expectation" hypothesis, which implies that litigants do not incur in systematic errors in their projections, and it is expected that, on average, their estimated probabilities about litigation outcomes are consistent with "true" population probabilities.

10 Galanter's theory has been tested empirically, mainly in the analyses of US Supreme Court decisions (see, for example, Wanner 1975; Sheehan 1992).

11 The cut-off date considered is August 1, 2020. A small number of cases wherein the tribunal's decision is not publicly available were removed from the initial list of 172 cases.

12 Retrieved from: icsid.worldbank.org.

13 Retrieved from: investmentpolicy.unctad.org.

14 Retrieved from: www.italaw.com.

15 Mexico adhered to ICSID in 2018 but this country has participated in a number of disputes at ICSID before that date. In this case, given that the obligation of submitting to IIA disputes between investors 
and governments was introduced through the North American Free Trade Agreement (NAFTA) we use the date of signature of this treaty instead.

16 Three proxies were initially considered: rule of law, regulatory quality, and government effectiveness. However, the first two variables were discarded because of the lack of significance.

${ }^{17}$ Estimates with correction for selection bias include unselected observations.

${ }^{18}$ For a critical analysis of Argentina's performance in ICSID, see Lavopa (2015).

${ }^{19}$ In contrast with the data used in estimations in previous sections, this information of disputes corresponds to registered cases, including cases pending awards. This explains, for example, why Colombia can be included, because there are 14 cases registered against this country, but still pending resolution.

${ }^{20}$ FDI for all countries is expressed in 2019 US dollars.

\section{References}

Barklem, C., \& Prieto-Ríos, E. (2011). The concept of indirect expropriation, its appearance in the international system and its effects in the regulatory activity of governments. Civilizar: Ciencias Sociales y Humanas, 21 (11), 77-97.

Behn, D., Berge, T., \& Lanforf, M. (2018). Poor states of poor governance? Explaining outcomes in investment treaty arbitration, Northwestern Journal of International Law \& Business, 38(3), 333-389.

Butler, N., \& Subedi, S. (2017). The future of international investment regulation: Towards a world investment organisation? Netherland International Law Review, 64, 43-72.

Chouduri, B. (2008). Recapturing public power: Is investment arbitration's engagement of the public interest contributing to the democratic deficit?, Vanderbilt Journal of Transational Law 41(3), 775-832.

Economic Commission for Latin America and the Caribbean (2005). Foreign Direct Investment 2006. (May) Santiago. 
Fiezzoni, S. (2011). The challenge of UNASUR member countries to replace ICSID arbitration. Beijing Law Review, 2, 134-144. DOI: 10.4236/ blr.2011.23014..

Franck, S., \& Wylie, L. (2015). Predicting outcomes in investment treaty arbitration. Duke Law Journal, 45, 460-526.

Franck, S. (2009). International investment arbitration: Winning, losing and why. Washington and Lee University School of Law Washington \& Lee University School of Law Scholarly Commons 6-15-2009. Retrieved from https://scholarlycommons.law.wlu.edu/.

Franck, S. (2005). The legitimacy crisis in investment treaty arbitration: Privatizing public international law through inconsistent decisions. Fordham Law Review, 73 (4), Article 10, 1521-1625.

Kidland F., \& Prescott E. (1977). Rules rather than discretion: the inconsistency of Optimal Plans. Journal of Political Economy, 85, 473492.

Heckman, J. (1979). Sample selection bias as a specification error. Econometrica, 47, 153-161. https://doi.org/10.2307/1912352

Galanter, M. (1974). Why the "haves" come out ahead: Speculations on the limits of legal change. Law \& Society Review, 9(1), Litigation and Dispute Processing: Part One, 95-160. https://doi.org/10.2307/3053023.

Guzman A. (1998). Why LDCs sign treaties that hurt them: Explaining the popularity of bilateral investment treaties. Virginia Journal of International Law, 38, 639-688.

ICSID. (2020). The ICSID case-load statistics. Issue 2020-1. Retrieved from https://icsid.worldbank.org/resources/publications/icsid-caseloadstatistics.

ICSID. (2019). The ICSID case-load statistics. Issue 2019-2. Retrieved from https://icsid.worldbank.org/resources/publications/icsid-caseloadstatistics.

ICSID. (2018). The ICSID case-load statistics. Issue 2018-2. Retrieved from https://icsid.worldbank.org/resources/publications/icsid-caseloadstatistics.

ICSID. (2017). The ICSID case-load statistics. Issue 2017-2. Retrieved from https://icsid.worldbank.org/resources/publications/icsid-caseloadstatistics 
Kauffman, D., Kraay, A., \& Mastruzzi, M. (2010). The worldwide governance indicators: Methodology and analytical issues. Policy Research Working Papers \#5430, World Bank.

Kessler, D., Meites, T., \& Miller, G. (1996). Explaining deviations from the fifty-percent rule: A multimodal approach to the selection of cases for litigation. The Journal of Legal Studies, 25(1), 233-259.

Lavopa, F. (2015). Crisis, medidas de emergencia y fracaso del mecanismo de SCIE: el caso de la Argentina. Informe sobre Políticas de Inversión (July), Centro del Sur.

Lokshin, M., \& Z. Sajaia. (2011). Impact of interventions on discrete outcomes: Maximum likelihood estimation of the binary choice models with binary endogenous regressors. Stata Journal, 11, 368-385.

Priest, G., \& Klein, B. (1984). The selection of disputes for litigation. The Journal of Legal Studies, 13(1), 1-55.

Roodman, D. (2011). Fitting fully observed recursive mixed-process models with cmp. The Stata Journal, 11(2), 159-206.

Sheehan, R. (1992). Governmental litigants, underdogs, and civil liberties: A reassessment of a trend in Supreme Court decision making. The Western Political Quarterly, 45(1), 27-39. https://doi. org/10.1177/106591299204500104

Schultz, T., \& Dupont, C. (2015). Investment arbitration: Promoting the rule of law or over-empowering investors? A quantitative empirical study. The European Journal of International Law, 25, 1147-1168. DOI: 10.1093/ ejil/chu075.

Siegelman, P., \& Waldfogel, J. (1999). Toward a taxonomy of disputes: New evidence through the prism of the priest/klein model. The Journal of Legal Studies, 28(1), 101-130.

Strezhnev, A. (2017) Why rich countries win investment disputes: Taking selection seriously, Mimeo. Retrieved from https://static1.squarespace. $\mathrm{com} / \mathrm{static} / 5931 \mathrm{baca} 440243906 \mathrm{ef} 65 \mathrm{ca} / \mathrm{t} / 59 \mathrm{c} 55 \mathrm{e} 2829 \mathrm{f} 187 \mathrm{ed} 71 \mathrm{a}$ ba071/1506106921710/why_rich_countries_win_investment_disputes.pdf

Sweet, A., \& Grisel, F. (2017). The Evolution of International Arbitration: Judicialization, Governance, Legitimacy. Oxford: Oxford University Press.

Tobin, J., \& Rose-Ackerman, S. (2011) When BIT have some bite: the political-economy environment for bilateral investment treaties. The Review of International Organizations 6, 1-32. DOI: 10.1007/s11558010-9089-y. 
UNCTAD. (2006). Bilateral Investments Treaties 1995-2006: Trends in Investment Rulemaking. United Nations: New York, UNCTAD/ITE/ IIT/2006/5.

UNCTAD. (2009). The Role of International Investment Agreements in Attracting Foreign Direct Investment to Developing Countries. UNCTAD Series on International Investment Policies for Development: New York.

Van Harten, G. (2012). Arbitrator behaviour in asymmetrical adjudication: An empirical study of investment treaty arbitration. Osgood Hall University Journal, 50(1), 211-268.

Vu, D. (2018). Reasons not to exit?: A survey of the effectiveness and spillover effects of international investment arbitration. Documents de Travail, GREDEG Working Paper Series \#35, Groupe de Recherche en Droit, Economie, Gestion (GREDEG CNRS), Université Côte d'Azur, France.

Vu, D. (2020). To settle or to fight to the end? Case-level determinants of early settlement of investor-state disputes. Review of Law and Economics, 17(1) 133-166. https://doi.org/10.1515/rle-2019-0046

Waibel, M., \& Wu, Y. (2017). Are arbitrators political? Mimeo. Retrieved from http://dx.doi.org/10.2139/ssrn.2101186.

Wanner, C. (1975). The public ordering of private relations: Part two: Winning civil court cases. Law \& Society Review, 9(2), Litigation and Dispute Processing: Part Two, 293-306. https://doi.org/10.2307/3052978 Wellhausen R. (2016) Recent trends in investor-state dispute settlement. Journal of International Dispute Settlement, 7(1), 117-135. DOI: 10.1093/jnlids/idv038

Yackee, J., \& Wong, J. (2010). The 2006 procedural and transparency-related amendments to the ICSID arbitration rules: Model intentions, moderate proposals, and modest returns. In The Yearbook on Investment Law \& Policy, Karl P. Sauvant (ed.), chap. 6, Oxford: Oxford University Press. Zhang, J. (2017). International investment arbitration: Development, controversies, and future. Retrieved from http://dx.doi.org/10.2139/ ssrn.3068727. 


\section{Appendix A}

Figure A.1: Number of LAC Countries that Adhered to ICSID

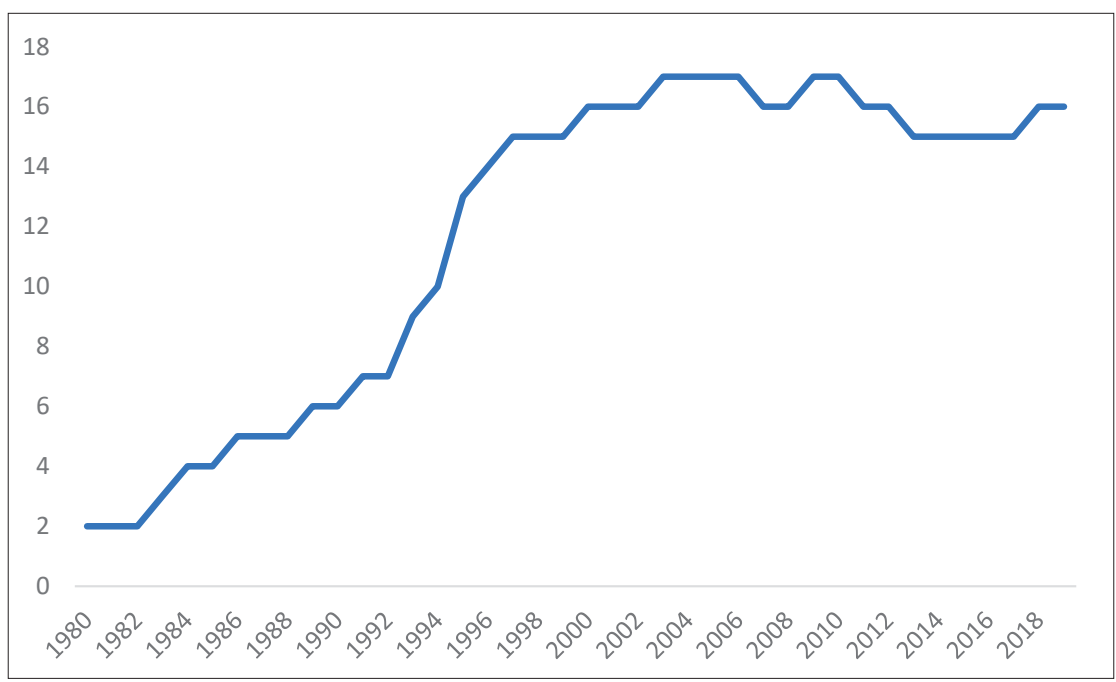

Source: ICSID, Elaboration: The author.

Figure A.2: Number of BITs Subscribed by LAC Countries

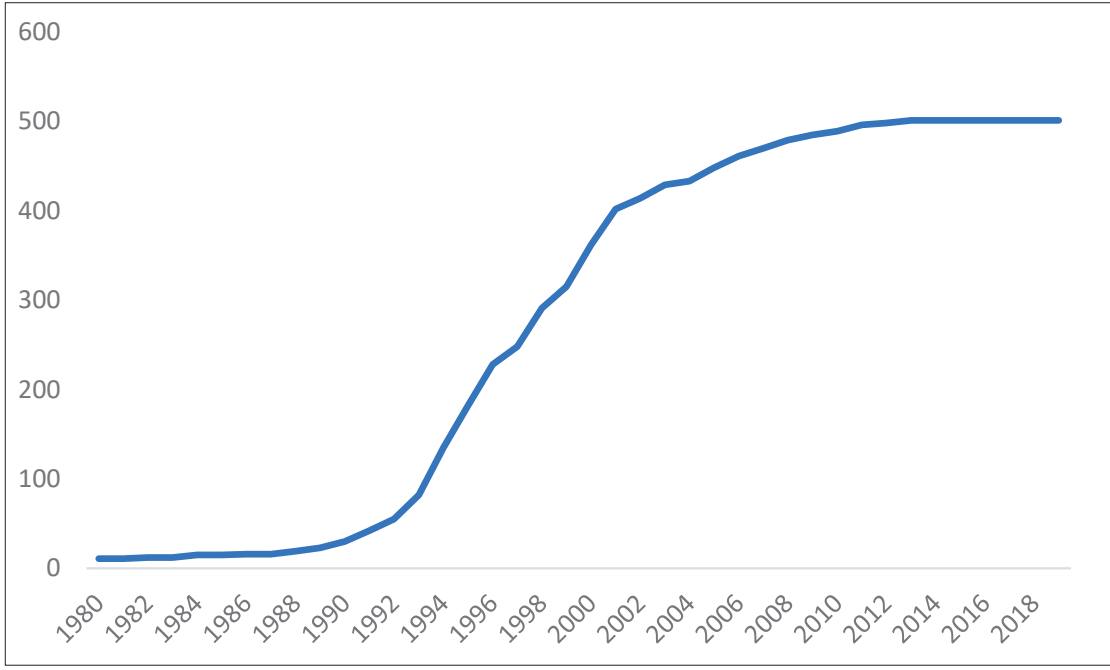

Source: ICSID, Elaboration: The author. 
Table A.1: Cumulative Number of BITs Signed by LAC Countries

\begin{tabular}{|c|c|c|c|c|}
\hline & 1980 & 1990 & 2000 & 2019 \\
\hline Argentina & 0 & 0 & 52 & 58 \\
\hline Bolivia & 0 & 3 & 18 & 23 \\
\hline Chile & 0 & 1 & 50 & 55 \\
\hline Colombia & 1 & 1 & 3 & 17 \\
\hline Dom. Republic & 1 & 1 & 5 & 15 \\
\hline Brazil & 0 & 0 & 14 & 14 \\
\hline Costa Rica & 1 & 1 & 14 & 20 \\
\hline Ecuador & 2 & 4 & 24 & 27 \\
\hline El Salvador & 0 & 0 & 16 & 20 \\
\hline Guatemala & 0 & 0 & 2 & 17 \\
\hline Hayti & 2 & 4 & 5 & 5 \\
\hline Honduras & 0 & 1 & 9 & 10 \\
\hline Jamaica & 0 & 2 & 12 & 13 \\
\hline Mexico & 0 & 0 & 12 & 32 \\
\hline Nicaragua & 0 & 0 & 11 & 18 \\
\hline Panama & 2 & 3 & 20 & 23 \\
\hline Paraguay & 2 & 2 & 21 & 25 \\
\hline Peru & 0 & 1 & 28 & 35 \\
\hline Trin. \& Tobago & 0 & 0 & 5 & 11 \\
\hline Uruguay & 0 & 5 & 19 & 34 \\
\hline Venezuela & 0 & 1 & 22 & 29 \\
\hline Total & 11 & 30 & 362 & 501 \\
\hline
\end{tabular}

Source: ICSID; Elaboration: The author. 


\section{Appendix B}

Table B.1: Number of LAC Country Cases Registered under ICSID

\begin{tabular}{lccccc}
\hline & Cases & Selected & Founded & Not Founded & Not Selected \\
\hline Argentina & 46 & 21 & 15 & 6 & 25 \\
Venezuela & 31 & 23 & 12 & 11 & 8 \\
Mexico & 17 & 16 & 9 & 7 & 1 \\
Peru & 15 & 12 & 3 & 9 & 3 \\
Ecuador & 12 & 7 & 4 & 3 & 5 \\
Costa Rica & 9 & 7 & 3 & 4 & 2 \\
Panama & 4 & 3 & 0 & 3 & 1 \\
Bolivia & 4 & 1 & 1 & 0 & 3 \\
El Salvador & 4 & 3 & 0 & 3 & 1 \\
Chile & 3 & 3 & 2 & 1 & 0 \\
Guatemala & 3 & 3 & 2 & 1 & 0 \\
Paraguay & 3 & 2 & 1 & 1 & 1 \\
Jamaica & 2 & 0 & 0 & 0 & 2 \\
Honduras & 2 & 2 & 2 & 0 & 0 \\
Uruguay & 2 & 2 & 0 & 2 & 0 \\
Trinidad \& Tobago & 2 & 1 & 0 & 1 & 1 \\
Dominican Republic & 1 & 1 & 0 & 1 & 0 \\
Nicaragua & 1 & 0 & 0 & 0 & 1 \\
\hline TOTAL & 161 & 107 & 54 & 53 & 54 \\
\hline
\end{tabular}

Source: ICSID, Elaboration: The author. 
Figure B.1: LAC Countries Cases Registered under ICSID

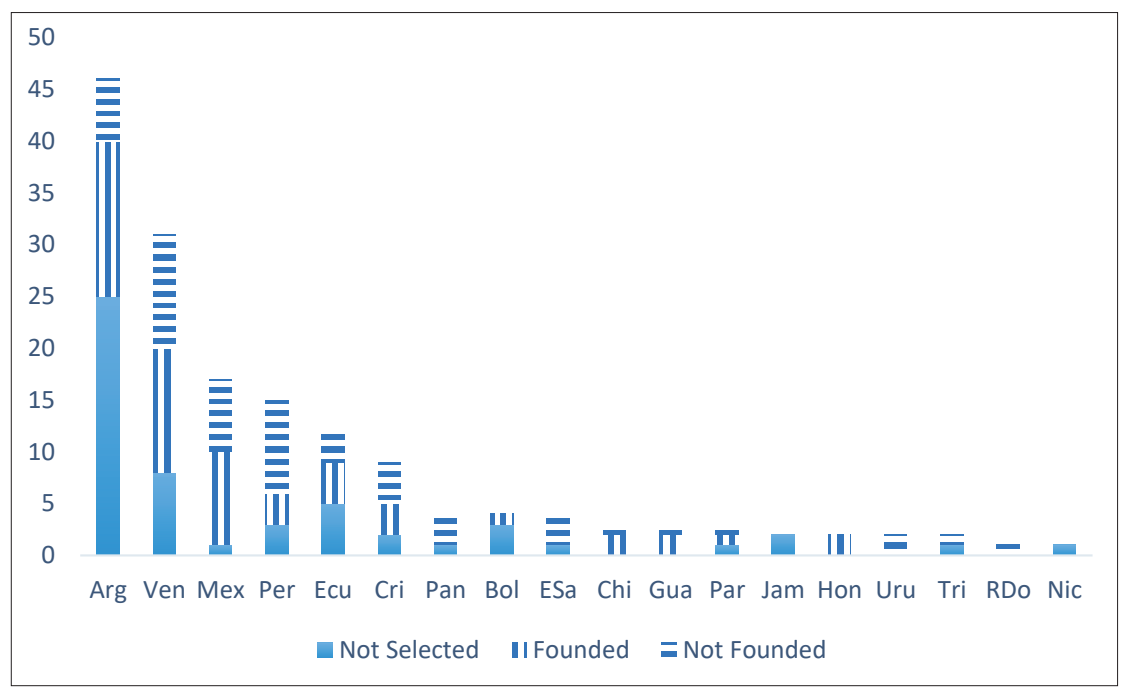

Source: ICSID, Elaboration: The author.

Table B.2: Founded Verdicts: Average Pretentions of Claimants by Country and Percentages Awarded

\begin{tabular}{|c|c|c|}
\hline & Average Claimed & Average \% Awarded \\
\hline Argentina & 531.0 & $38.2 \%$ \\
\hline Venezuela & 839.6 & $43.6 \%$ \\
\hline Mexico & 107.1 & $48.9 \%$ \\
\hline Peru & 202.9 & $21.5 \%$ \\
\hline Ecuador & 884.7 & $68.7 \%$ \\
\hline Costa Rica & 48.0 & $43.2 \%$ \\
\hline Bolivia & 71.1 & $73.6 \%$ \\
\hline Chile & 243.5 & $30.5 \%$ \\
\hline Guatemala & 168.7 & $14.5 \%$ \\
\hline Paraguay & 68.3 & $63.5 \%$ \\
\hline Honduras & 10.5 & $84.4 \%$ \\
\hline Total Average $^{1 /}$ & 448.1 & $44.6 \%$ \\
\hline
\end{tabular}

Note: 1/. Total average corresponds to all the cases and is not the single average of countries' outcomes.

Source: ICSID, Elaboration: The author. 
Table B.3: Sample Characteristics

\begin{tabular}{|c|c|c|c|c|c|c|c|}
\hline \multirow[b]{2}{*}{ Variable } & \multicolumn{5}{|c|}{ Total Sample } & \multirow{2}{*}{$\begin{array}{c}\text { Mean } \\
\text { Selected } \\
\text { Sample }\end{array}$} & \multirow{2}{*}{$\begin{array}{c}\text { Mean Not } \\
\text { Selected } \\
\text { Sample }\end{array}$} \\
\hline & Obs & Mean & Std. Dev & Min & $\operatorname{Max}$ & & \\
\hline Selected $_{i}$ & 161 & 0.66 & 0.47 & 0.00 & 1.00 & 1.00 & 0.00 \\
\hline Founded $_{i}$ & 107 & 0.50 & 0.50 & 0.00 & 1.00 & 0.50 & - \\
\hline Lstaker $_{i}$ & 161 & 5.15 & 1.64 & -0.07 & 9.33 & 4.93 & 5.59 \\
\hline Dexprop $_{i}$ & 161 & 0.30 & 0.46 & 0.00 & 1.00 & 0.28 & 0.35 \\
\hline Geffect $_{i}$ & 161 & -0.30 & 0.56 & -1.23 & 1.20 & -0.28 & -0.34 \\
\hline$L g d p p c_{i}$ & 161 & 9.21 & 0.39 & 7.92 & 9.99 & 9.21 & 9.22 \\
\hline Preslatam $_{i}$ & 107 & 0.27 & 0.45 & 0.00 & 1.00 & 0.27 & - \\
\hline Numcaseclai $_{i}$ & 161 & 1.50 & 1.01 & 1.00 & 7.00 & 1.39 & 1.72 \\
\hline Tesinceicsid $_{i}$ & 161 & 12.53 & 5.87 & 1.00 & 36.00 & 12.68 & 12.24 \\
\hline Infinel $_{i}$ & 161 & 0.27 & 0.45 & 0.00 & 1.00 & 0.20 & 0.43 \\
\hline
\end{tabular}

